\title{
Characteristics of World-class Enterprises' Employee: An Empirical Study Based on Big-data
}

\author{
Xiaofeng Zhanga , Li Ma, Guowei Gao, Haixu Song, Cai Liang, and Haiyun Song \\ State Grid Energy Research Institute, Beijing 102209, China \\ ${ }^{a}$ sgerizxf@163.com
}

Keywords: employee characteristics; world-class enterprises; big data

\begin{abstract}
The rise of a country requires support from a group of outstanding companies, and employees with excellent quality are required in the way of stepping toward world-class enterprises. Under the background of economic globalization and increasingly development of globally competitive world-class enterprises, it is imperative to build an employee quality that is compatible with the goals of world-class enterprises. The purpose of this paper is to analyze characteristics of employees in world-class enterprises based on the big data of recruitment information, and put forward recommendations for companies.
\end{abstract}

\section{Introduction}

The rise of country requires support from a group of outstanding companies, who must need employees with excellent quality in the way of stepping toward world-class enterprises ${ }^{[1]}$. Based on competency quality theory, competency of employees is the ability to meet job requirements and to adapt to the organizational environment. Individual competencies include: knowledge - the information needed in a certain occupation field; skills - the ability to grasp and apply specialized skills; social roles - the individual's knowledge and understanding of social norms; self-recognition the identity of oneself Perception and evaluation; traits - the characteristics of a person or his typical behavior; motivation - the idea or idea of determining the inherent stability of explicit behavior ${ }^{[2,3]}$.

Under background of economic globalization and increasingly development of globally competitive world-class enterprise, it is imperative to build an employee quality that is compatible with the goals of world-class enterprises. The purpose of this paper is to analyze characteristics of employees in world-class enterprises based on the big data of recruitment information, and put forward conclusions and recommendations for companies.

\section{Research Sample}

361 positions from 210 companies were selected as an analysis sample based on principles of importance, relevance, and convenience. The positions are mainly management and functional positions at the headquarters and supplemented by professional and technical positions. The 
companies are selected according to authoritative lists, such as Fortune Global 500 list in 2017, world's most valuable 500 brand list, performance evaluation of central enterprises.

\section{Analytical Method}

A text analysis was conducted to refine the characteristics that world-class enterprises expect from their headquarters staff based on recruitment information of the research sample which is provided on the official website. Firstly, employee characteristics indicators involved in positions were identified through content analysis of recruitment information of each company. Secondly, frequencies of key characteristic indicators are statistically extracted as a weight which reflect the importance of the indicators. Thirdly, relationships between entities are extracted through clustering similar indicators.

\section{Analysis Conclusion}

Big data analysis shows that features of world-class enterprises' requirement for employees are summarized as follows.

Firstly, in the view of feature classification, in addition to basic characteristics such as academic background and work experience, the requirements for employees in world-class enterprises mainly include five aspects: self-management, collaborative execution, value creation, environmental adaptation and international perspective. In terms of self-management, world-class enterprises often put forward clear requirements for employees' time management capabilities, resource integration capabilities and organizational capabilities. In terms of collaborative execution, they mainly value employees' teamwork ability, communication level and providing guidance. In terms of value creation, the requirements are innovative thinking, value discovery and service awareness. Requirement of environmental adaptation mainly includes adaptability, learning ability and resilience. International perspectives mainly includes international practices and regulations, language level, cross-cultural communication, global perspective and international activities.

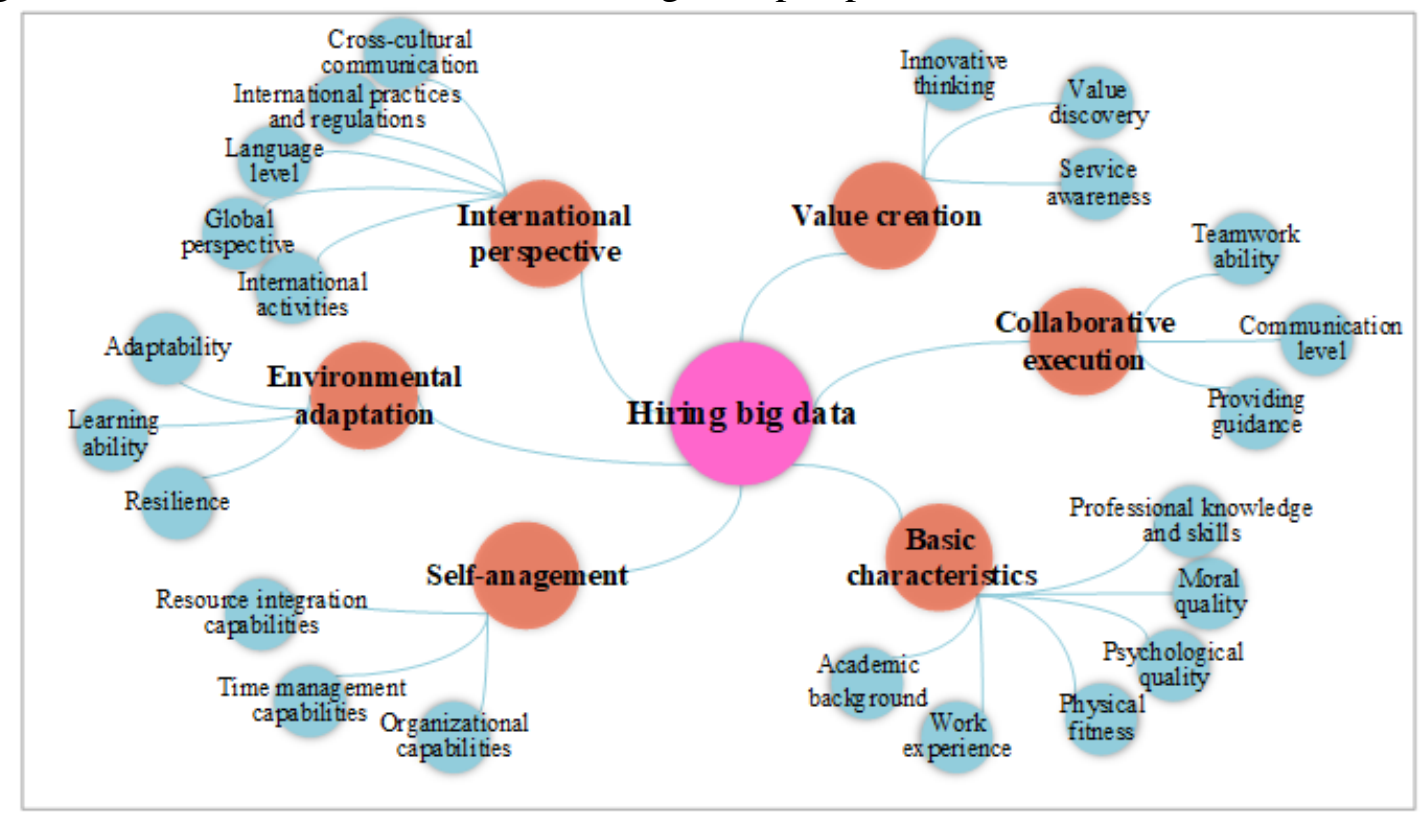

Fig. 1 Feature classification of employees in world-class enterprises 
Secondly, from the perspective of importance, the top 10 most valued employees' features ${ }^{1}$ are teamwork ability, professional knowledge and skills, learning ability, resilience, value discovery, service awareness, resource integration capability, innovative thinking, global perspective and language level.

Teamwork ability occurs 254 times in the requirement of 361 selected positions and ranks first with weight $69.8 \%$. Team is the smallest and most important business process unit of enterprise. Only integrating into team, as well as combining personal efforts with achieving team's objectives to improve the overall performance of the team, it can be possible to support enterprise's outstanding performance. Therefore, teamwork ability is the most valued employees' feature for the world-class enterprises.

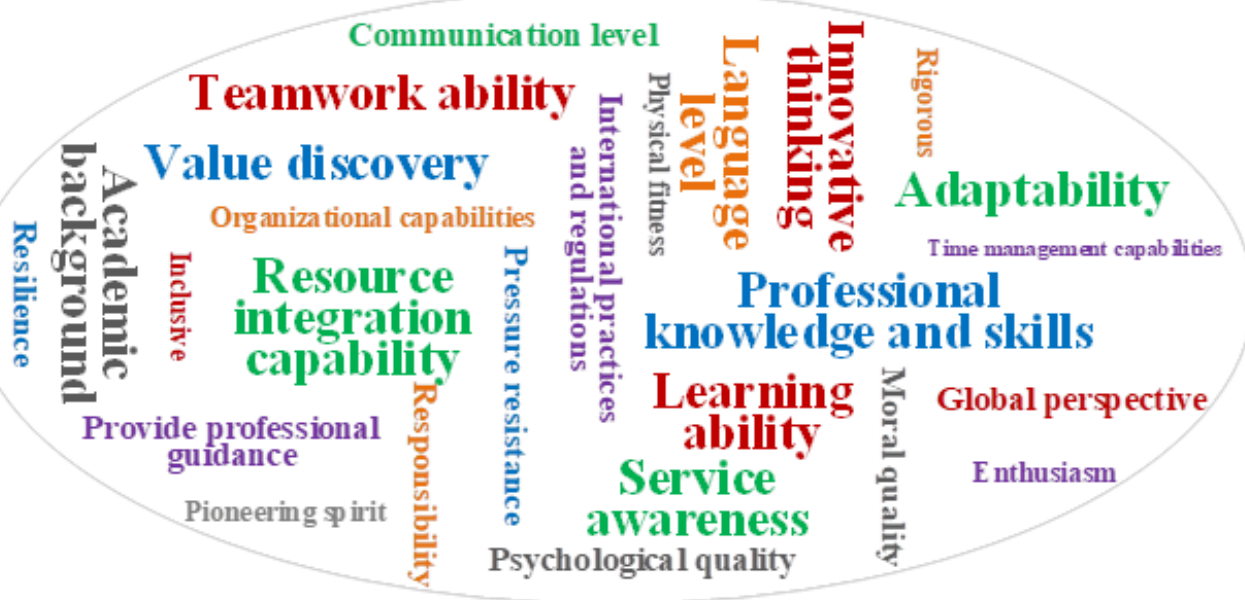

Fig. 2 Big data word cloud illustration of employees’ features in world-class enterprises

Professional knowledge and skills ranks second with weight $65.4 \%$. High-skilled employees are the foundation for sustainable development of enterprises. Although world-class enterprises have different sets of business positions, their requirements for employees' professional knowledge and skills related to business are at the core.

Learning ability and resilience ranks third and fourth with weights $62.1 \%$ and $58.2 \%$ respectively. At present, technologies, such as big data, Clouds, IoT, Mobile Internet and AI, are being infiltrated and applied to human production and life with unprecedented speed. Meanwhile, cross-border operations and disruptive innovation are emerging in an endless stream. To adapt and lead complex and profound changing external environment, world-class enterprises must require employees to have high level learning ability and resilience.

Value discovery, innovative thinking, service awareness and resource integration capabilities rank from fifth to eighth. The weight of value discovery is $56.9 \%$, which emphasizes that employees should have the ability to discover new things, grasp development direction and keenly identify potential value for the company. The weight of creative thinking is $56.0 \%$, which requires breaking traditional thinking and contributing novel ideas. World-class enterprises also require employees to have customer service sense and emphasize the "every customer-centric" service concept. The weight of service awareness is $54.4 \%$. The weight of resource integration capabilities is $53.0 \%$, which emphasis employees' organizational coordination capabilities and global outlook. Resource integration capabilities requires employees to allocate and utilize limited resources, such as people, finances, materials, and information, reasonably and efficiently.

\footnotetext{
${ }^{1}$ The basic requirements for employees' features, such as academic background and work experience, are not included in the rankings.
} 
In addition, the top ten features also include language level and global perspective. Global business transactions and negotiations of world-class enterprises require employees to have good language level. At the same time, enterprises require employees to have global perspective, closely follow the world economic and social development trends and observe the economic operation and enterprises' development from broader perspective. The requirement of global perspective could support enterprises to take the initiative in international competition.

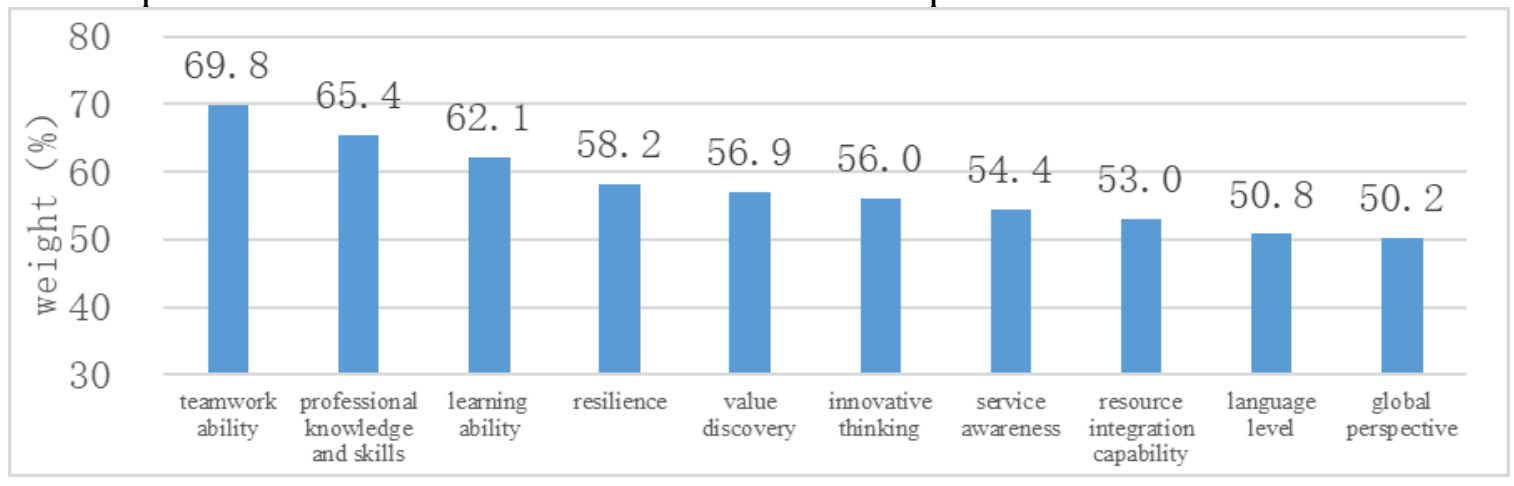

Fig. 3 Top 10 features of world-class enterprises’ employee

Table 1 Frequency results of employees’ characteristics in world-class enterprises

\begin{tabular}{|c|c|c|c|c|c|c|c|}
\hline No. & Indicator & $\begin{array}{c}\text { Frequenc } \\
\mathrm{y} \\
\end{array}$ & $\begin{array}{c}\text { Weight } \\
(\%)\end{array}$ & No. & Indicator & $\begin{array}{c}\text { Frequenc } \\
\mathrm{y} \\
\end{array}$ & $\begin{array}{c}\text { Weight } \\
(\%)\end{array}$ \\
\hline 1 & Teamwork ability & 254 & 69.8 & 15 & $\begin{array}{l}\text { International practices } \\
\text { and regulations }\end{array}$ & 158 & 43.4 \\
\hline 2 & Acdamic backgroud & 246 & 67.6 & 16 & Leadership & 153 & 42.0 \\
\hline 3 & Work experience & 243 & 66.8 & 17 & $\begin{array}{l}\text { Time management } \\
\text { capabilities }\end{array}$ & 147 & 40.4 \\
\hline 4 & $\begin{array}{c}\text { Professional } \\
\text { knowledge and skills }\end{array}$ & 238 & 65.4 & 18 & $\begin{array}{l}\text { Providing professional } \\
\text { guidance }\end{array}$ & 142 & 39.0 \\
\hline 5 & Learning ability & 226 & 62.1 & 19 & $\begin{array}{l}\text { Adaptability } \\
\text { International }\end{array}$ & 138 & 37.9 \\
\hline 6 & Resilience & 212 & 58.2 & 20 & $\begin{array}{l}\text { professional } \\
\text { qualification }\end{array}$ & 123 & 36.5 \\
\hline 7 & Value discovery & 207 & 56.9 & 21 & Organizational skills & 115 & 31.6 \\
\hline 8 & Innovative thinking & 204 & 56.0 & 22 & Psychological quality & 106 & 29.1 \\
\hline 9 & Service awareness & 198 & 54.4 & 23 & $\begin{array}{l}\text { Cross-cultural } \\
\text { communication skills }\end{array}$ & 101 & 27.7 \\
\hline 10 & $\begin{array}{l}\text { Resource integration } \\
\text { capability }\end{array}$ & 193 & 53.0 & 24 & Physical fitness & 93 & 25.5 \\
\hline 11 & Language level & 185 & 50.8 & 25 & $\begin{array}{l}\text { Independent } \\
\text { international activities }\end{array}$ & 82 & 22.5 \\
\hline 12 & Global perspective & 183 & 50.2 & 26 & Pressure resistance & 74 & 20.3 \\
\hline 13 & Responsibility & 165 & 45.3 & 27 & Moral quality & 55 & 15.1 \\
\hline 14 & $\begin{array}{l}\text { Cross-cultural } \\
\text { communication }\end{array}$ & 161 & 44.2 & 28 & National Spirit & 21 & 5.8 \\
\hline
\end{tabular}

\section{Inspiration and Suggestions}

Firstly, with the goal of becoming world-class enterprises, Chinese enterprises need to raise the employees' characteristic requirements to a strategic height and simultaneously take various 
measures to create a high-quality employee team. To achieve qualitative breakthrough of employees' quality improvement, enterprises can innovate talents' benchmark evaluation concept, strengthen external recruitment, carry out internal training to tap potential employees, and promote construction of human resources markets.

Secondly, to build a world-class enterprises, it is necessary to focus on upgrading the five features of employees, which are self-management, collaborative execution, value creation, environmental adaptation and international perspective. In addition to basic features such as high-level professional knowledge and skills, it is also necessary to focus on enhancing employees' teamwork ability, learning ability, resilience, value discovery and customer service awareness. Especially in the business areas that are in close contact with customers, enterprises need to draw on the "Internet concept" to strengthen employees' market awareness, competitive awareness and customer service awareness.

\section{References}

[1] Huo Yubao, the importance of improving the quality of employees in state-owned enterprises, J. Modern Enterprise, 10 (2017) 31-32.

[2] Wang Xun, Suggestions and Measures to Improve the Employees' Ability and Quality, J. Shopping Mall Modernization. 12(2017) 116-117.

[3] Qi Linsun, Research on the training of knowledge workers in the era of big data, J. Journal of Jilin Radio \& TV University. 11(2017) 128-129. 